\title{
The Right to Life in a SuICIDAL State
}

Mr Neil Allen

Lecturer, University of Manchester (Manchester), and Barrister, Thirty Nine Essex Street Chambers (London, Manchester and Singapore)

$+44(0) 1612754480$

neil.allen@manchester.ac.uk

Suicide prevention may be a key national priority in many countries, but the common law of negligence has traditionally been reluctant to oblige the State and its citizens to prevent others from taking their own life. An individualist philosophy dissuades us from being our brother's keeper, preferring us to look after ourselves and to take responsibility for our actions. Whilst legislation promotes good Samaritanism in certain parts of the world, the common law of negligence positively discourages it in others by rendering rescuers liable for bungling an intervention, despite their best of intentions.

Recent developments in human rights law are slowly realigning historically divergent legal and moral obligations towards those in a suicidal state of mind. This article will focus on the circumstances in which a suicidist's right to life may trump the law regarding omissions by positively requiring the State to intervene to preserve life. After analysing the concept of an "autonomous suicide" and its ethical boundaries, the civil liability for acts and omissions in the face of suicide shall be outlined and the 'ugly Samaritan' exposed. Attention will then shift to the interlocking human rights which bear upon notions of respect for physical and moral integrity, a 
dignified death, and the right to life. When must the State intervene to frustrate the intentions of an identified individual desirous of death in light of those competing principles?

The central thesis will be that whenever and wherever public authorities know or ought to know of a real and immediate risk to life to an identifiable person, they must take reasonable precautions to minimise it. In deciding what is reasonable and what precautions should be taken, the law must ensure that a disproportionate burden is not placed upon the State. Moreover, when the person is intent on suicide, precautionary reasonableness will also be heavily dependent upon the counterbalancing notions of autonomy and dignity. Some final thoughts will then be given to the difficulties arising from this positive operational duty and its future relationship with the law of negligence.

\section{ARE THERE Limits to An "Autonomous SuICIDE"?}

At common law, people are generally entitled to act as they please, even if death will inevitably

result. $^{1}$ So competent adults have an absolute right to fatally refuse medical treatment ${ }^{2}$ (Wicks,

${ }^{1}$ Reeves v. Commissioner of Police of the Metropolis [2000] 1 AC 360, at 379-380.

${ }^{2}$ Airedale NHS Trust v. Bland [1993] AC 789, at 865; Re T (Adult: Refusal of Medical Treatment) [1993] Fam 95, at 102; In Re MB (medical treatment) [1997] 2 FLR 426, at 432. Different considerations apply to minors. 
2010) or to jump to their death. ${ }^{3}$ Unless Parliament decrees otherwise, to compel us to live for longer than we wish will usually be a criminal and civil assault. ${ }^{4}$ This stark legal position mirrors the libertarian ethical principle of non-interference. In legal terms, according to Justice Cardozo, 'every human being of adult years and sound mind has a right to determine what shall be done with his own body'. ${ }^{5}$ Whilst in ethical terms, according to John Stuart Mill, '[o]ver himself, over his own body and mind, the individual is sovereign' and our 'own good, either physical or moral, is not a sufficient warrant' for intervention (Mill, 1859, p. 22). These often-cited legal and ethical perspectives sit comfortably side by side and portray the traditional notion of individual autonomy.

The consequences of respecting an autonomous decision are clearly gravest when people wish to suicide, whether by refusing life-saving treatment or by some other means. ${ }^{6}$ But that gravity does

${ }^{3}$ Suicide Act 1961 section 1 (England and Wales) decriminalised the act of suicide: 'The rule of law whereby it is a crime for a person to commit suicide is hereby abrogated.' Whether this thereby created a 'right to die' is considered below.

${ }^{4}$ St George's Healthcare NHS Trust v. S [1999] Fam 26, at 62. Conversely, whilst a patient may refuse treatment, they cannot demand it: $R$ (on the application of Burke) $v$. General Medical Council [2005] EWCA Civ 1003, at [50].

${ }^{5}$ Schloendorff v. Society of New York Hospital (1914) 211 NY 125, at 128.

${ }^{6}$ The courts tend to distinguish treatment refusals from suicide: Airedale NHS Trust v. Bland [1993] AC 789, at 864. Owing to its artificiality, no such distinction is drawn here where a treatment refusal results in immediate death: e.g. see $B$ v. An NHS Hospital Trust [2002] EWHC 429 (Fam) where the patient made a competent request to have her ventilator switched off. 
not undermine the force of the principle: autonomy will hold firm. Arguably a fatal decision is when the principle is needed most. Ronald Dworkin, for example, described how '[w]e allow someone to choose death over radical amputation or a blood transfusion, if that is his informed wish, because we acknowledge his right to a life structured by his own values' (Dworkin, 1993, p. 239). Therein lies autonomy's intrinsic value. The Supreme Court of the United Kingdom has recognised the dominance of autonomy in death decisions: '[a]utonomous individuals have a right to take their own lives if that is what they truly want. ${ }^{, 7}$ Indeed, perhaps human freedom demands nothing less. Otherwise the very concept of human freedom is at risk of becoming merely illusory. This virtuous stance is of course heavily premised, both in law and in ethics, with at least four notes of caution: mental capacity, emergencies, harm to others and the competing bioethical principles.

First, mental capacity. The approach to autonomy of both Cardozo J. and Mill is premised upon the person having the mental capacity, or 'the ordinary amount of understanding' (Mill, 1859, p. 84), to make the fatal decision. However, opinions differ as to whether there can even be such a concept as an "autonomous suicide". Is suicidal ideation necessarily indicative of mental ill health? Or can a person competently decide to want to end their life? Ethical, psychiatric and legal views abound and space permits merely the briefest of insights into the debate. A standard reading of Immanuel Kant, for example, suggests that suicide is always irrational and unethical (Kant, 1964). ${ }^{8}$ Whereas Thomas Schramme argues that suicide is not an immoral act and the

\footnotetext{
${ }^{7}$ Rabone v. Pennine Care NHS Foundation Trust [2012] UKSC 2.

${ }^{8}$ For an alternative understanding, see Cooley, D.R., 'A Kantian care ethics suicide duty' (2013) International Journal of Law and Psychiatry.
} 
desire to die may be rational when the person does not see a meaning in life (Schramme, 2013). In psychiatric circles, Beauchamp and Childress note that 'many persons who commit suicide are mentally ill, clinically depressed, or destabilized by a crisis and are, therefore, not acting autonomously' (Beauchamp, 2001, p. 189). Whereas Jeanette Hewitt contends that rational suicide may be a justifiable option for those with mental illness (Hewitt, 2013).

No doubt many who have suicidal intent are mentally unwell and in crisis. But many are not. Some people want to end their life prematurely - or shorten their prolonged death - for all sorts of reasons. Their state of mind should not inevitably be labelled as 'mentally disordered'. And those with a psychiatric diagnosis should not inevitably be assumed to lack the capacity to decide to suicide. The issue is, are they able to make that decision? Aside from mental disorder, all sorts of internal and external pressures may or may not influence one's ability to decide. Emotions, experiences, and environments may come to bear. But what matters is whether the person can decide in spite of those influences. The Death with Dignity Act 1997 in Oregon, for example, acknowledges that mental disorder may not automatically impair suicidal decision-making abilities but its presence may call for increased vigilance, routine psychiatric assessment and counselling before the person is assisted to implement their final decision.

The common law similarly recognises that the mentally ill are able to retain the ability to decide on matters of life and death. ${ }^{9}$ The High Court of Australia, for example, noted that '[w]hile attempted suicide may be indicative of mental illness, it is not necessarily so'. ${ }^{10}$ The Supreme

\footnotetext{
${ }^{9} \operatorname{Re} C$ (Adult Refusal of Treatment) [1994] 1 All ER 819.

${ }^{10}$ Stuart v. Kirkland-Veenstra [2009] HCA 15, at [5].
} 
Court in the United Kingdom has similarly acknowledged the wriggle room for autonomy between a psychiatric diagnosis and a capacitous suicidal decision: 'In the case of the suicide of a psychiatric patient, the likelihood is that, given the patient's mental disorder, her capacity to make a rational decision to end her life will be to some degree impaired'. ${ }^{11}$ It shall therefore be taken as read that the concept of an "autonomous suicide" does exist, at least in legal if not also in ethical terms, for those with or without a psychiatric diagnosis.

The second note of caution surrounding the respecting of fatal decisions concerns emergency situations. Mill's liberal philosophy recognises that temporary intervention is justified in order to ascertain whether a person is acting autonomously. Drawing on his wayfarer example, if someone is about to jump from a cliff edge, Mill would no doubt permit a bystander to intervene to see whether the jumper has the 'ordinary amount of understanding' and to warn them of their impending peril. Even if they are acting autonomously, according to Mill '[ $\mathrm{t}] \mathrm{here}$ are good reasons for remonstrating with him, or reasoning with him, or persuading him, or entreating him, but not for compelling him' (Mill, 1859, p. 22). A useful legal illustration of this moral stance involved Mrs Z. She had an incurable degenerative brain disease. Her husband informed their local authority of her plan to travel to Zurich for suicide assistance. The High Court temporarily interfered by way of an interim injunction restraining him from removing his wife from the country whilst expert evidence was sought regarding her capacity to make the fatal decision. The

${ }^{11}$ Rabone v. Pennine Care NHS Foundation Trust [2012] UKSC 2, at [30] (Lord Dyson) (emphasis added). Similarly, at [106] Lady Hale noted, '[Melanie's] mental disorder meant that she might well lack the capacity to make an autonomous decision to take her own life' (emphasis added). 
day before the trip, the uncontested evidence was that she had 'all the requisite attributes necessary to establish legal capacity to make her own decisions'; the decision was entirely uninfluenced by outside considerations; and it was long-held and in the face of the contrary wishes of her family. The injunction was therefore lifted and Dignitas assisted her suicide. Reinforcing the individualist philosophy of the common law, the Judge held: 'This case simply illustrates that a competent person is entitled to take their own decisions on these matters and that that person alone bears responsibility for any decision so taken.' 12

The third limit to the principle of non-interference is the recognition that power can be rightfully exercised over an autonomous person against their will in order to prevent harm to others. In particular, Mill accepted that if the person's actions violated 'a distinct and assignable obligation to any other person or persons, the case is taken out of the self-regarding class, and becomes amenable to moral disapprobation' (Mill, 1859, p. 145). This obligation to others need not be legal in nature; it could be moral. So Mill gives the example of a man who, having undertaken the moral responsibility of a family, becomes incapable of supporting them through intemperance or extravagance. The breaching of his moral duty towards his family and financial creditors, rather than the extravagance itself, would warrant interference with his autonomy. How might this relate to suicide? Clearly 'no person is an entirely isolated being' (Mill, 1859, p. 143) and an autonomous suicide is rarely an isolated act, immune from harmful repercussions. Others experience its aftermath. Emotional or psychological harm may be felt by family, friends, the community, and, let us not forget, those health and social care professionals with whom the person comes into contact. As with Mill's example, financial harm may also be caused to the

\footnotetext{
${ }^{12}$ A Local Authority v. Z [2004] EWHC 2817 (Fam) at [21].
} 
suicidist's dependents and creditors. Such harmful ripples are readily foreseeable from the decisional epicentre of someone contemplating the taking of their own life. But do they give rise to a 'distinct and assignable obligation' that would justify suicide prevention?

Margot Brazier makes a strong case that patients owe ethical duties to others, including doctors: '[i]t is empowerment of patients which brings responsibilities' (Brazier, 2006, p. 401). Recognising these moral duties to take account of others' interests, she says, is not antithetical to respect for autonomy and they do not disappear simply because the person becomes a patient. This reflects communitarian ethics; that in judging the ethics of a course of action (or omission), the impact on the community and not just the individual themselves must be evaluated (Callaghan, 2003) (Etzioni, 2011). However, 'clothing such ethical responsibilities with legal force is a harder task' (Brazier M. and Cave, E., 2011, p. 69). For Mill, law need not clothe them; moral tailoring would suffice. But whether these obligations can be translated into law is far from certain, with many attendant risks. Mary Donnelly notes, for example, 'by carefully situating the individual at the centre of her web of relationships, one risks losing the individual altogether' which, taken to the extreme, might otherwise lead to a 'duty to die' (Donnelly, 2010, p. 35$).^{13}$

By the end of the twentieth century, autonomy appeared to have become a dominant - perhaps the dominant - principle: so dominant in fact as to lead Daniel Callaghan to state, 'Nothing has exasperated me so much as the deference given in bioethics to the principle of autonomy' (Callaghan, 1996). As Donnelly observes, its status as a principle of non-interference has until

\footnotetext{
${ }^{13}$ Referring to Hardwig, J., 'Is there a Duty to Die?' (1997) 27 Hastings Center Report 34.
} 
recently been largely uncontested in health care law (Donnelly, 2010, p. 49). However, it is not the sole bioethical principle at stake and its primacy has been brought into question. For example, Justice Maurice Kay (as he then was) stated: 'it would seem to me a matter of deep regret if the law has developed to a point in this area where the rights of a patient count for everything and other ethical values and institutional integrity count for nothing. ${ }^{14}$ The law may respect autonomous decisions to suicide, but it cannot compel others to implement them. Doctors cannot be forced by the patient or the judiciary to switch off the ventilator of an irreversibly paralysed patient who has competently decided to suicide. ${ }^{15}$ Health and social care professionals surely have the right to make autonomous choices too. And 'if medical integrity has no ethical value, medical ethics itself becomes irrelevant' (Brazier M. , 2006, p. 420).

In their influential writings, Beauchamp and Childress advanced three other principles to accompany autonomy: justice, beneficence, and non-maleficence (Beauchamp, 2001). ${ }^{16}$ Justice requires the cornerstones of the law: equality and fairness. The law's reaction to physician assisted suicide, or what one might call 'beneficent suicide', is outside the scope of this article, save to note the potential impact of the beneficence principle for those seeking, but unable to

\footnotetext{
${ }^{14}$ R v. Collins and Ashworth Hospital Authority, ex p. Brady [2000] Lloyd's Rep. Med. 355.

${ }^{15}$ B v. An NHS Hospital Trust [2002] EWHC 429 (Fam). Dame Butler-Sloss ordered that arrangements be made to comply with the patient's request but would not order her clinicians to switch it off. B said in her evidence "I fully accept the doctor's right to say 'I personally will not do it",' (at 461).

${ }^{16}$ Criticised by Clouser, K.D. and Gert, B. 'A Critique of Principalism' (1996) 15 Journal of Medicine and Philosophy 210.
} 
bring about, their own dignified death. ${ }^{17}$ Rather, it is the third principle of non-maleficence, or doing no harm, as reflected in the common law by the duty of care, to which we shall now turn.

\section{THE GOOD, THE BAD, AND THE UGLY SAMARITAN}

For as long as suicide was a crime there was a corresponding law-enforcement obligation on the State to prevent it. Decriminalisation has removed that positive obligation, leaving uncertainty in its wake. Many civil law countries have enacted Samaritan laws to minimise the risk of harm (Malm, 1995) (Malm, 2000). Some protect good Samaritans by affording citizens immunity from civil liability for bungled rescues. Others punish bad Samaritans by criminalising a failure to rescue. Under section 323c of the German Criminal Code, for example, omitting to effect an easy rescue can result in up to one year's imprisonment or a fine. But no such obligation arises if the person is attempting suicide because the peril is viewed as an act of will, at least where the person is not mentally disordered (Gordley, 2006, pp. 369-370). Many common law systems have followed a similar suit. In the United States there has been a recent trend towards some level of codification in all 50 States to deter bad Samaritanism (Fulbrook, 2013). But there is little consensus as to exactly what should be required of the rescuer.

The law of tort in England and Wales encourages what we might term the 'ugly Samaritan': that is, someone who is positively discouraged from intervening and potentially liable if they do

\footnotetext{
${ }^{17} R$ (Nicklinson and others) v. Ministry of Justice [2013] EWCA Civ 961.
} 
intervene and make matters worse. ${ }^{18}$ It thus generally imparts no beneficent legal obligation upon public authorities or citizens to protect others from harm. Perhaps raising a moral eyebrow, pure omissions in the absence of a duty of care are not therefore unlawful. ${ }^{19}$ Whether there is a duty depends on the familiar tripartite test in Caparo Industries Plc v. Dickman. ${ }^{20}$ Was the harm reasonably foreseeable? Was the parties' relationship sufficiently proximate? And would it be fair, just and reasonable to recognise a duty? Note therefore that simply foreseeing harm, even death, triggers no duty to prevent it. ${ }^{21}$

In the context of suicide, it follows that at common law neither the citizen nor the State is under any general obligation to prevent a person who wants to take his or her own life. Even if the authorities know of a real and immediate risk of suicide, they generally need not prevent it. ${ }^{22}$ No

${ }^{18}$ Vividly illustrated in Handiboe v. McCarthy 114 Ca. App. 541. 151 S.E. $2 d 905$ (1966) where the Georgia Court of Appeal held that a servant was under no duty to rescue a 4-year-old child who was drowning in his master's three foot deep swimming pool.

${ }^{19}$ Smith v. Littlewoods Organisation Ltd [1987] AC 241, 271; Yuen Kun Yeu v. Attorney General of Hong Kong [1988] AC 175, 192; Stovin v Wise [1996] AC 923, 929-936; Gorringe v Calderdale Metropolitan Borough Council [2004] 1 WLR 1057.

${ }^{20}$ [1990] 2 AC 605, 618 (Lord Bridge).

${ }^{21}$ Dorset Yacht Co.Ltd v. Home Office [1970] AC 1004, at 1037-1038; Hill v. Chief Constable of West Yorkshire [1989] AC 53, at 60; Mitchell v. Glasgow City Council [2009] 1 AC 874, 890.

${ }^{22}$ Savage v. South Essex Partnership NHS Foundation Trust [2009] AC 681, at [11] (Lord Scott). For the equivalent rule in Australia, see Stuart v. Kirkland-Veenstra [2009] HCA 15, at [8]. 
civil or criminal liability will arise by watching a suicidist leap to their death unless a duty of care exists between the observer and the observed; a duty which may on the facts be triggered by deciding to intervene. According to leading commentators, 'whenever a professional undertakes to provide a service for another person knowing that the latter reasonably relies on his professional competence and judgment, a duty of care will arise' (Clerk and Lindsell, 2012, para. 10-05). A bungled intervention may render them liable in negligence if they make the situation worse. $^{23}$ So neither the priest nor the Levite would have incurred civil liability in English law unless they intervened and botched it. ${ }^{24}$

The fundamental role played by the duty of care is vividly illustrated in the Australian case of Stuart $v$ Kirkland-Veenstra. ${ }^{25}$ It was 5.40am when two police officers saw a tube running from the exhaust pipe into the window of a parked car. Inside was Ronald Veenstra. He had been there for two hours. The engine was cold. He persuaded them that, although he had been about to do something stupid, he had changed his mind and was going home to talk to his wife. He sounded rational and was responsive to their questions. He removed the tube and, having declined the officers' offers of assistance, drove from the car park. They thought he was depressed but not mentally ill. Although contemplating suicide, they did not believe he was going to take his own life. Later that day he did, using the tube in his car at home. The High Court of Australia held

${ }^{23}$ Capital and Counties Plc v. Hampshire County Council [1997] QB 1004, at [49].

${ }^{24}$ For a discussion of the 'neighbour' test and Samaritanism see Donoghue v. Stevenson [1932] A.C. 562, at 580, Hargrave v. Goldman (1963) 110 C.L.R. 40, at 66, and Dorset Yacht Co. Ltd v. Home Office [1970] AC 1004, at 1060.

${ }^{25}[2009]$ HCA 15. 
that the police did not owe him a duty of care. The officers had no power to remove him to a place of safety because they did not believe him to be mentally ill or suicidal. Moreover, even if that power could have been exercised, no legal duty to do so would have arisen as this would mark 'a significant departure from an underlying value of the common law, which gives primacy to personal autonomy'. ${ }^{26}$ Thus there was no legal duty to rescue another from a risk which the bystander neither created nor had any control over.

Even adopting Mill's philosophy as our moral position, let alone any more paternalistic stance, it would still stand poles apart from our common law obligations. The justification for ugly Samaritanism is the priority given to individual autonomy and the corresponding reluctance to require us to act as our brother's keeper. Its repugnance to modern thinking was recognised by Lord Goff in 1987 who said it may have to be reconsidered one day. ${ }^{27}$ Indeed, the absence of a duty of care meant the Australian officers would not have even been required to approach the car, let alone carry out the checks they did. Their precautionary steps no doubt reflected their professional obligations, but not their legal ones. At its ugliest, no legal liability in negligence would have arisen had they simply stood next to the car and watched Mr Veenstra inhale exhaust fumes to his death. ${ }^{28}$ What difference would or should human rights law make? Did he have the right to be left alone, even the right to suicide? Or should his right to life have taken primacy?

${ }^{26}$ Stuart v. Kirkland-Veenstra [2009] HCA 15, at [87].

${ }^{27}$ Smith v. Littlewoods Organisation Ltd [1987] AC 241, at 271.

${ }^{28}$ In $R v$. Dytham [1979] QB 722, a police officer was convicted of misconduct in public office for failing to intervene whilst a man was kicked to death. But his misconduct was calculated to 


\section{A MYRIAD OF SUICIDAL "RIGHTS"}

Suicide may no longer be a crime but did its decriminalisation confer a 'right' to suicide? John Coggon observes that 'being allowed to do something is not always equivalent to having a right to do it' (Coggon, 2006, p. 219). If such a right did exist, it would be a peculiar stance for the law to take to then imprison those who encourage or assist the suicidist to exercise that right. ${ }^{29}$ And how would it equate with the right to life? The European Convention on Human Rights and Fundamental Freedoms 1950 ('ECHR') protects 800 million people across the Council of Europe and shall be used as the platform to analyse these issues. The very essence of the Convention is respect for human dignity and human freedom ${ }^{30}$ and the appropriate response to suicidal decisions requires us to consider three interlocking human rights. The first is Article 8 which provides a qualified right to respect for suicidal decisions. The second is Article 3 which prohibits degrading treatment that may be experienced during the course of the suicidal process. And, finally, Article 2 - the most fundamental - protects the right to life. No informed stance on suicide can be taken without considering all three.

injure the public interest so as to call for condemnation and punishment, whereas non-feasance would not have sufficed.

${ }^{29}$ Suicide Act 1961 section 2 provides a maximum punishment of fourteen years.

${ }^{30}$ Pretty v. United Kingdom (2002) 35 EHRR 1, at [65]. 
The right to be 'left alone, is inherent in Article 8, ${ }^{31}$ It protects part of the crux of a free society by requiring the State to respect four domains of human life: private life, family life, home, and correspondence. At least in human rights law terms, therefore, one yardstick for determining the boundaries of a free society is by reference to whether something is accepted by the courts as constituting an interference with Article 8. The most relevant domain to suicide is 'private life' as this includes the protection of both our physical and moral integrity. ${ }^{32}$ Note that the Convention does not confer a right to private life. Rather, it provides a right to respect for private life which imports positive obligations, for it is difficult to 'respect' something passively. Moreover, an 'interference' with this right must be distinguished from a 'violation' of it, for Article 8 is not absolute. It is qualified. State interference is therefore permitted if it accords with the law and is necessary in a democratic society for the protection of, for example, a suicidist's health or morals or the rights and freedoms of others.

Being at risk of forfeiting mental capacity because others disagree with one's suicidal decision would amount to an interference. ${ }^{33}$ Most significantly for our purposes, the European Court of Human Rights has now recognised that deciding the manner and moment of death is similarly protected, so long as the person is 'capable of freely reaching a decision on this question and acting in consequence' ${ }^{34}$ It follows that, firstly, someone cannot be automatically deemed to lack

\footnotetext{
${ }^{31}$ Malone v. United Kingdom (1985) 7 EHRR 14, at 55.

${ }^{32} X$ and $Y v$. The Netherlands (1986) 8 EHRR 235, at [22]-[23].

${ }^{33}$ A Primary Care Trust v. P [2009] EW Misc 10, at [58].

${ }^{34}$ Haas v. Switzerland (2011) 53 EHRR 33, at [51]; Koch v. Germany (2013) 56 EHRR 6, at
} [52]; and Gross v. Switzerland [2013] ECHR 429 at [59]. 
capacity just because their decision relates to how and when they wish to die. And, secondly, the right to respect for that decision is premised on the person (a) making an autonomous decision, and (b) being able to act on it. At this stage in the development of the jurisprudence, none of this confers a 'right' to suicide. ${ }^{35}$ And, as Coggon contends, 'it is contrary to reason to suggest that there can be no right to die but that there can be a right to die with dignity. I accept, however, that it is plausible that the right to die could only be invoked in the context of Article 3, and thus only as a right to die with dignity' (Coggon, 2006, p. 232).

Article 3 prohibits torture, inhuman and degrading treatment. The English courts have yet to definitively rule as to whether this absolute prohibition provides a right to die with dignity. ${ }^{36}$ However, Munby J. (as he then was) has previously held that 'Article 3 embraces the right to die with dignity and the right to be protected from treatment, or from a lack of treatment, which will result in one dying in avoidably distressing circumstances'. ${ }^{37}$ In this context, 'treatment' could go beyond medical treatment to include State intervention more generally. ${ }^{38}$ Patients with capacity subjectively determine their own concept of dignity. The dignity of those lacking capacity would, it was held, be determined by a right-thinking observer. Moreover, his Lordship

${ }^{35}$ Pretty v. United Kingdom (2002) 35 EHRR 1, at [39]; R (Nicklinson and others) v. Ministry of Justice [2013] EWCA Civ 961.

${ }^{36}$ The right was recognised in An NHS Trust v. D [2000] 2 FLR 677, at [82].

${ }^{37}$ At first instance in $R$ (on the application of Burke) v. General Medical Council [2004] EWHC 1879 , at [137]. Although the appeal was allowed, this point was left answered at [2005] EWCA Civ 1003.

${ }^{38}$ Pretty v. United Kingdom (2002) 35 EHRR 1, at [52]. 
recognised that, as well as autonomy, dignity may sometimes take priority over the sanctity of life: 'any obligations of the State under Article 2 must ... accommodate its obligations under Article $3{ }^{39}$

Article 2 protects the right to life and the European Court has held that it 'cannot, without a distortion of language, be interpreted as conferring on an individual the diametrically opposite right, namely a right to die; nor can it create a right to self-determination in the sense of conferring on an individual the entitlement to choose death rather than life, ${ }^{40}$ Lives are protected by imposing three duties upon the State. The first is a negative duty to refrain from taking life, save in prescribed exceptional circumstances. The second is a procedural duty to investigate deaths (or near deaths) for which it might bear some responsibility, usually met by the coronial systems. The third is a positive duty to take steps to protect our lives. It consists of two limbs: (a) a general duty to put in place a legislative and administrative framework designed to provide effective deterrence against threats to life; and (b) an operational duty to protect life in certain circumstances. The general duty 'must be construed as applying in the context of any activity, whether public or not, in which the right to life may be at stake ${ }^{41}$ It requires the State to adopt appropriate measures for securing high professional standards to protect life. In the sphere of public and private health care, the framework regulates the acts and omissions of health

\footnotetext{
${ }^{39} R$ (on the application of Burke) v. General Medical Council [2004] EWHC 1879, at [129].

${ }^{40}$ Pretty v. United Kingdom (2002) 35 EHRR 1, at [39].

${ }^{41}$ Öneryildiz v. Turkey (2005) 41 EHRR 20, at [71].
} 
professionals through the law of tort and regulatory law, for example. ${ }^{42}$ But it does not obligate a specific result. By way of example, it may require a regulatory framework to be put in place for rescuing mountain climbers in distress; but it does not demand a deadline within which aerial ambulances must reach a particular climber. ${ }^{43}$ The focus of this article is on the operational duty which is more onerous and can be owed to an individual.

\section{The Operational Duty to Save Life}

Given the ugly English Samaritan, it is perhaps no coincidence that the key Strasbourg cases regarding the operational duty were decided against the government of the United Kingdom. It was first recognised in Osman v. United Kingdom. ${ }^{44}$ For public policy reasons, the police could not be held liable in negligence for failing to prevent loss of life from the criminal acts of others. Nonetheless, the Strasbourg Court accepted that the police could be liable under Article 2, although not on the particular facts. In a key passage it ruled:

${ }^{42}$ See Dodov v. Bulgaria (2008) 47 EHRR 41, at [70], [79]-[83] and [87]; Byrzykowski v. Poland (2008) 46 EHRR 32, at [104] and [106]; Vo v. France (2005) 40 EHRR 12, at [89]-[90]; Tarariyeva v Russia (2009) 48 EHRR 26, at [74]; Powell v. United Kingdom (2000) 30 EHRR CD 362, at 364 .

${ }^{43}$ Furdik v. Slovakia (2009) 48 EHRR SE9 146.

${ }^{44}$ (2000) 29 EHRR 245. 
'116. For the Court, and bearing in mind the difficulties involved in policing modern societies, the unpredictability of human conduct and the operational choices which must be made in terms of priorities and resources, such an obligation must be interpreted in a way which does not impose an impossible or disproportionate burden on the authorities. Accordingly, not every claimed risk to life can entail for the authorities a Convention requirement to take operational measures to prevent that risk from materialising... [I]t must be established to its satisfaction that the authorities knew or ought to have known at the time of the existence of a real and immediate risk to the life of an identified individual or individuals from the criminal acts of a third party and that they failed to take measures within the scope of their powers which, judged reasonably, might have been expected to avoid that risk. The Court does not accept the Government's view that the failure to perceive the risk to life in the circumstances known at the time or to take preventive measures to avoid that risk must be tantamount to gross negligence or wilful disregard of the duty to protect life... For the Court, and having regard to the nature of the right protected by Article 2, a right fundamental in the scheme of the Convention, it is sufficient for an applicant to show that the authorities did not do all that could be reasonably expected of them to avoid a real and immediate risk to life of which they have or ought to have knowledge. This is a question which can only be answered in the light of all the circumstances of any particular case.'

So the Court envisaged that, despite the absence of a duty of care, the police could owe the operational duty to those in the community whose life was threatened by others. The elements of the Osman test thus prescribe the trigger for invoking this positive precautionary obligation. It 
can be owed to any identified individual if the police know, or ought to know, of a real and immediate risk to that person's life. This degree of foresight sets a very high threshold which is not readily satisfied (McBride, 1999). Actual or constructive knowledge of the risk is required. The risk must be to life, not just to limb, so knowledge of a real and immediate risk of injury alone would not suffice. And the real risk must be present and continuing at the time of the alleged violation; if its immediacy subsides before the expectation to take precautions arises, the necessary causal link may found wanting.

Establishing the duty is not easy; proving its breach is harder. A claimant must prove that the relevant authority failed to do all that could reasonably be expected to avoid the risk to life. The principle of proportionality embraced by the European jurisprudence is key here. States have a wide margin of appreciation in relation to the taking of precautionary measures which aim to strike a fair balance between individual and community rights. Organs of the State cannot, and should not, be expected to prevent every real and immediate risk to life: such an absolute standard would be an impossible and disproportionate burden and would threaten our free society. Reasonableness is the standard to be expected. And this requires consideration of which precautionary options were available, what their likely effectiveness would be, and the ease or difficulty of implementing them, taking into the resources available.

The test is said to be 'clear and calls for no judicial exegesis' ${ }^{45}$ Both the Strasbourg and English jurisprudence has recognised that the Osman elements are self-supporting. They are determined

${ }^{45}$ Van Colle v. Chief Constable of the Hertfordshire Police [2009] 1 AC 225, at [30] (Lord Bingham); confirmed in Van Colle v. United Kingdom (2013) 56 EHRR 23, at [91]. 
on their own, without recourse to other legal standards. Thus, the United Kingdom's attempt to require the elements to be tantamount to gross negligence or a wilful disregard of the duty to protect life was rejected in Osman. Whether the risk to life emanates from the State, the person, or from a third party makes no difference in this regard to the nature of the Osman test of responsibility. As the Court stated in Van Colle v. United Kingdom:

'The Court notes that the Osman test has been applied by this Court in numerous cases where the State can be considered to have placed the individual in a vulnerable position. No reference was made in any of those cases to changing the Osman test or the threshold which had to be reached to satisfy that test ... ${ }^{46}$

It can thus be seen that the ECHR approach to suicide differs to the traditional judicial review of public authority liability. No duty of care is even required and rather than determining whether the authority's failure was 'so unreasonable that no reasonable authority could ever have come to it' $^{, 47}$ the Article 2 approach contains its own judicial standard of reasonableness. Even a superWednesbury approach - by which the Court would engage in a particularly intensive review but not substitute itself for the statutory decision-maker - does not provide a sufficient standard of review. Rather, the pre-eminent right to life calls for a full merits review.

\footnotetext{
${ }^{46}$ Van Colle v. United Kingdom (2013) 56 EHRR 23, at [91].

${ }^{47}$ Associated Provincial Picture Houses Ltd v. Wednesbury Corpn [1948] 1 KB 223, at 234.
} 
The duty has been recognised in a diverse range of circumstances where the risk is to another person's life: from detention release,${ }^{48}$ and domestic violence, ${ }^{49}$ through to the management of dangerous activities ${ }^{50}$ and political journalism. ${ }^{51}$ Should the jurisdictional remit of the protective duty be circumscribed where the claimed risk to life arises, not from the criminal acts of a third party, but from the right-bearer themselves? The first significant decision addressing this was Keenan v United Kingdom. ${ }^{52}$ Mark Keenan was mentally ill with acute psychotic episodes and paranoia. He was imprisoned for assault and, shortly before the end of his sentence, was placed in solitary confinement after an aggressive outburst, during which he hanged himself. The disciplinary punishment breached Article 3. But insofar as his right to life was concerned, the government contended that to require the State to protect a person against himself would be inconsistent with the principles of individual dignity and autonomy which should prohibit any oppressive removal of a person's freedom of choice and action. The Court noted that general measures and precautions to diminish the opportunities for self-harm are available, without infringing personal autonomy, and ' $[\mathrm{w}]$ hether any more stringent measures are necessary in respect of a prisoner and whether it is reasonable to apply them will depend on the circumstances

${ }^{48}$ Tomašic v. Croatia (Application no. 46598/06, 15 January 2009); Mastromatteo v. Italy (Application no. 37703/97, 24 October 2002); Bromiley v. United Kingdom (Application no. 33747/96, 23 November 1999).

${ }^{49}$ Opuz v. Turkey (Application no. 33401/02, 9 June 2009).

${ }^{50}$ Öneryildiz v. Turkey (2005) 41 EHRR 20; LCB v. United Kingdom (1998) 27 EHRR 212.

${ }^{51}$ Gongadze v. Ukraine (2006) 43 EHRR 44.

${ }^{52}$ (2001) 33 EHRR 913. 
of the case'. ${ }^{53}$ Crucially, it recognised that the operational duty could be owed to suicidal prisoners, although on the day there was no particular indication that he was likely to make an attempt on his life, despite his self-harming tendencies. The risk was real but not immediate. ${ }^{54}$

Since then, the United Kingdom's highest Court has taken the lead in developing the protection afforded by the operational duty to suicidal patients and Strasbourg has followed. Carol Savage was detained for treatment under the Mental Health Act 1983 and, left unsupervised, was able to abscond and jump in front of a passing train at a nearby rail station. The Court accepted that the duty could be owed to a detained patient on account of her vulnerability by reason of her illness and the hospital authority's control. ${ }^{55}$ The hospital was subsequently found to have violated Article 2 by failing to take reasonable precautions to avoid the real and immediate risk to life. Fifteen or even thirty minute observations would not have been an unreasonable step to require of the hospital and would have brought a real prospect of her not slipping away unnoticed as she did. $^{56}$

Melanie Rabone was informally admitted to a locked ward suffering from depression. She was observed every 15 minutes having attempted suicide three times in the previous seven weeks. After a week, with her mood appearing to lift, the psychiatrist granted her request to go home for the weekend, against the wishes of her concerned parents. The following day she was found

\footnotetext{
53 (2001) 33 EHRR 913, at [92].

${ }^{54}$ (2001) 33 EHRR 913, at [98].

${ }^{55}$ Savage v. South Essex Partnership NHS Foundation Trust [2009] AC 681, at [49].

${ }^{56}$ Savage v. South Essex Partnership NHS Foundation Trust [2010] EWHC 865.
} 
hanging from a tree. The Court held that the operational duty could be owed to informal psychiatric patients 'where there has been an assumption of responsibility by the state for the individual's welfare and safety (including by the exercise of control) ${ }^{57}$ On the facts, there was a real and immediate risk to life and the hospital violated Article 2 by failing to take reasonable precautions. The medical treatment she received was fragmented and discontinuous. Staff had not been trained in the use of the hospital Trust's new care programme approach policy. Old forms were still being used. Her psychiatrist's decision to grant leave was negligent. And no documented risk reassessment was undertaken before leave was granted, with no support plan having been put in place for that weekend. Thus, although reasonableness 'required consideration of respect for the personal autonomy of Melanie', as well as the ease or difficulty of taking precautions and the resources available, the duty was breached. ${ }^{58}$ Had she insisted on leaving, she should have been compulsorily detained to protect her right to life.

Soon after, the European Court agreed that the duty could be owed to an informal patient. ${ }^{59}$ David Reynolds was admitted to hospital, hearing voices telling him to kill himself. During the assessment he confirmed that he did not want to do so, was considered to be a low suicide risk and agreed to an informal admission. Shortly before his next dose of medication, he broke the window which had not been reinforced and jumped from the sixth floor to his death. The Court said it was properly arguable that the operational duty was owed which had not been fulfilled.

\footnotetext{
${ }^{57}$ Rabone v. Pennine Care NHS Foundation Trust [2012] UKSC 2, at [22].

${ }^{58}$ Rabone v. Pennine Care NHS Foundation Trust [2012] UKSC 2, at [43].

${ }^{59}$ Reynolds $v$. United Kingdom (2012) 55 EHRR 35.
} 
But can the duty be owed to suicidal persons in the community? In Mammadov $v$ Azerbaijan ${ }^{60}$ a woman covered herself in petrol in protest at the authorities' decision to evict her family from an illegally occupied dwelling. She then committed suicide by setting herself alight. The Strasbourg Court recognised that the duty could be owed in these circumstances: 'in a situation where an individual threatens to take his or her own life in plain view of state agents and, moreover where this threat is an emotional reaction directly induced by the state agents' actions or demands, the latter should treat this threat with the utmost seriousness as constituting an imminent risk to that individual's life, regardless of how unexpected that threat might have been.' On the facts, whilst the police may at least in part have been responsible for her death, there was insufficient evidence to conclude whether they could or should have done more.

Thus, having first confined the duty to suicidal prisoners and army conscripts before extending it to detained and then informal psychiatric patients, the jurisprudence now seems to be at the point of recognising that the operational duty is capable of being owed to individuals in the community. ${ }^{61}$ This, it is suggested, is a welcome development. Of course being in the hands of the State may make the risk of suicide more foreseeable. But the State could equally be aware of a real and immediate suicidal risk in circumstances outside its immediate control. The reality, the immediacy, and the knowledge of the risk may be more remote. Human behaviour may be more unpredictable. The availability of precautions may be less. It may be less reasonable to expect those precautions which are available to be taken. But all of these considerations are relevant to

\footnotetext{
${ }^{60}$ (Application no. 4762/05).

${ }^{61}$ Rabone v. Pennine Care NHS Foundation Trust [2012] UKSC 2, at [97]-[99] (Lady Hale).
} 
whether the duty is in fact owed and is, on the facts, breached. They are not preconditions to its very existence.

\section{SOME IMPLICATIONS}

Suicidal states of mind require a careful balance to be struck between risk and liberty, between paternalism and self-determination. For those who lack suicidal capacity, and are therefore not able to act autonomously, there will of course be a greater legal and ethical justification for intervention. But for those who are able to make a purported suicidal decision, the balance is particularly acute and ultimately may, as we shall see, "simply" require judicial double-checking. The interlocking nature of the human rights at stake is illustrated by Kerrie Wooltorton's suicide. She was 26-years-old, diagnosed with borderline personality disorder and would typically attempt suicide by ingesting antifreeze before accepting life-sustaining treatment. Three days after preparing an advance directive, on the Friday she swallowed antifreeze for the final time, called an ambulance and, on the hospital ward, accepted pain relief but refused renal dialysis. The renal physician assessed her capacity to refuse; "It's in the letter" was all she would say. Despite not otherwise engaging in the assessment process, she was deemed to have capacity, her fatal decision was respected and she died on the Sunday. The coroner concluded that it would have been unlawful to intervene: this was an autonomous suicide.

Her death has sparked a significant debate (Dyer, 2009) (McLean, 2009) (Callaghan S. a., 2011). Did she really have capacity? Should her psychiatrist not have examined her on the day? Could 
she not have been compulsorily detained and treated in spite of her capacity to refuse? Translating the events into human rights terms, Article 8 protected her right to respect the manner and moment of her death if the suicidal decision was made competently and if she could act accordingly. By calling an ambulance and being admitted onto the hospital ward, Wooltorton's decision impacted upon the medical integrity of those professionals with whom she came into contact. By involving the health authority in her act of suicide there was clearly a known real and immediate risk to her life from the ingestion of anti-freeze and the operational duty was triggered. The hospital was therefore obliged to take reasonable precautions to avoid it. Unusually, she was considered not to be detainable under the Mental Health Act 1983 and clearly those complying with Article 2 can only be expected to take measures that are within the scope of their powers. But given the emergency, would it not have been reasonable to get the capacity issue before a judge, as with Mrs Z? This would have ensured that there was a judicial double-checking of an apparently autonomous choice.

The risk to life was obvious in Wooltorton's case as she had acted upon her suicidal intent. But predicting risk in advance, whether to self or to others, is an inherently unreliable exercise. Psychiatry 'is not an exact science'; ${ }^{62}$ law is not an exact art. But risk pervades both disciplines. Psychiatry is expected to be able to predict risk to life and some psychiatrists feel (understandably) ill equipped to do so (Szmukler, 2003) (Ryan, 2010) (Large, 2011) (Singh, 2011). The meta-analysis undertaken by Matthew Large and colleagues found that merely $3 \%$ of 'high risk' patients can be expected to suicide in the year after hospital discharge, whilst about

${ }^{62} R$ (on the application of B) $v$ Ashworth Hospital Authority [2005] 2 AC 278, at [31] (Lady Hale). 
$60 \%$ of those patients who in fact go on to suicide are likely to be categorised as 'low risk' (Large M. S., 2011). In their view, psychiatrists should stop trying to guess which inpatients will suicide: 'Rational risk management for inpatient suicide involves the careful attention to the safety of hospital environments, the optimal care of each patient's illness and appropriate responses to each patient's circumstances' (Large M. R., 2011). Clinicians are like insurance agents: they sort patients into risk categories determined by actuarial studies, rather than gamble on the outcome of a particular horse race. The remaining $97 \%$ of 'high risk' patients would therefore, to continue the metaphor, be paying a higher premium - in terms of their deprived liberty and compulsory treatment - but may never make a claim on their life. So, says Ryan and colleagues, '[j] ust as insurance agents do not attempt to predict which customers will have their car stolen or smashed, so mental health clinicians are not predicting which patients will come to, or cause, harm. An accurate prediction of future violence or self-harm is impossible' (Ryan C. N., 2010). They call for risk categorisation to be abandoned and for capacity to be preferred as a basis for involuntary treatment, with no element of augury.

Assessing the risk of suicide may be thought by some to be of limited value in psychiatric practice, but the operational duty demands a determination of its reality and immediacy. There is nothing unique about this: many other aspects of the law depend upon risk, which, at least in human rights terms, is ultimately a legal evaluation. Therapeutic risks must be taken even when life is at risk, otherwise the balance between paternalism and self-determination will become distorted towards oppression. The Courts are alive to the risk of defensive practice. In Savage, for example, Baroness Hale said the operational duty 'should not persuade the professionals to behave any more cautiously or defensively than they are already persuaded to do by the ordinary 
law of negligence' ${ }^{63}$ Indeed, the threshold for triggering it has rarely been shown. In those circumstances, what does the operational duty add to what is already protected by the law of negligence and other legislative and administrative frameworks?

A human right of course does not need to 'add' anything to the law to justify its existence. It underpins the law, with the ECHR providing a floor rather than a ceiling of rights. Be that as it may, the operational duty does in reality supplement the more general duty under Article 2. First, as Spencer observes and Osman illustrates, much like Heineken beer (according to its advertisers), the duty can refresh those parts of the civil law that tortious principles cannot reach (Spencer, 2008). Owing the Osman duty without owing the common law duty of care is but one example. Second, for grieving families it adds proper recognition that their deceased's right to life was violated. A declaration to that effect is often far more valuable and meaningful than any insurance payout in a negligence claim. It serves as an acknowledgement that the State has breached the most fundamental of human rights, rather than as a mechanism for simply compensating the loss left behind. ${ }^{64}$ 'Just satisfaction' differs to 'financial satisfaction' in this regard. Third, for the parents deprived of the life of their adult child, the operational duty

${ }^{63}$ Savage v. South Essex Partnership NHS Foundation Trust [2009] AC 681, at [100] (Lady Hale).

${ }^{64}$ Rabone v. Pennine Care NHS Foundation Trust [2012] UKSC 2 awarded $£ 5000$ to each parent. In Savage v. South Essex Partnership NHS Foundation Trust [2010] EWHC 865 £10,000 was awarded to the deceased's daughter. 
provides a legal standing that they are denied by the law of tort. ${ }^{65}$ And, finally, in the determination of legal rights, it replaces the Wednesbury unreasonableness approach in judicial review proceedings and the Bolam peer-review adopted in negligence claims with a full merits level of scrutiny of the acts and omissions of public authorities. So rather than deciding whether the authority's decision or conduct in the face of the risk was 'so unreasonable that no reasonable authority could ever have come to it', or whether it accorded with a responsible body of relevant opinion, the judiciary itself will determine reasonableness according to its own standard. ${ }^{66}$

Although the duty may have arisen from the remnants of perceived deficiencies with the law of tort, its current existence and future development is certainly not dependent upon it. In some cases, like Rabone, the Article 2 claim ran alongside an action in negligence. In other cases, like Savage, it was free-standing. The relationship between Convention and common law rights is still feeling its way. There is, as du Bois points out, a 'stark divergence' between them (Du Bois, 2012). ${ }^{67}$ Must the duty of care follow the operational duty? Or might this lead to a form of good Samaritanism by the Strasbourgian back door? The Article 2 duty has been variously described

${ }^{65}$ Fatal Accidents Act 1976 section 1A prevents a claim by parents for damages for bereavement for any child over 18 .

${ }^{66}$ According to the Strasbourg Court, 'The Court must subject allegations of breach of [article 2] to the most careful scrutiny' (Nachova and Others v. Bulgaria (2006) 42 EHRR 43 at [93]). See also Van Colle v. United Kingdom (2013) 56 EHRR 23, at [91].

${ }^{67}$ See generally, D. Nolan, 'The Liability of Public Authorities for Failing to Confer Benefits' (2011) 127 Law Quarterly Review 260. 
as 'much more stringent ${ }^{68}$ than the duty of care and 'different from and in practice more difficult to establish than negligence ${ }^{69}$ According to Beatson, in the realms of positive obligations the Convention 'characteristically imposes demanding requirements of justification and proportionality which have no counterpart in the law of negligence' (Beatson, 2008, pp. 6-144). Establishing reasonable foreseeability is said to be less demanding than actual or constructive knowledge of a real and immediate risk to life. ${ }^{70}$ As Donal Nolan notes, actionable damage is a prerequisite in negligence but not for an alleged Convention violation (Nolan, 2013, p. 308). Moreover, where compensation is required to provide just satisfaction for an Article 2 breach, it can cover distress, anxiety, and helplessness which would not be recoverable in tort. He also identifies the Convention's approach to causation as being more relaxed than under domestic negligence law. Nolan favours the independent development of liability in negligence and under the Convention. Private law and public law 'are autonomous normative systems with their own distinctive rationales, concepts and core principles' (Nolan, 2013, p. 317).

\section{The Public Samaritan: A General Duty to Act Reasonably?}

${ }^{68}$ Van Colle v. Chief Constable of the Hertfordshire Police [2009] 1 AC 225, at [91].

${ }^{69}$ Savage v. South Essex Partnership NHS Foundation Trust [2009] AC 681, at [99]. See also Van Colle v. Chief Constable of the Hertfordshire Police [2009] 1 AC 225, at [115] (Lord Brown).

${ }^{70}$ Mitchell v. Glasgow City Council [2009] 1 AC 874, at [63] (Lady Paton); Rabone v. Pennine Care NHS Foundation Trust [2012] UKSC 2, at [37] (Lord Dyson). 
Across the Council of Europe, suicidal citizens have the right to require public authorities to take reasonable precautions to avoid their death if they ought to know of a real and immediate risk to life. Although the law develops incrementally, it is clear from the decision in Mammadov that the operational duty is not confined to prisons and psychiatric hospitals but can be owed to those who are suicidal in the community. No artificial legal boundaries, like 'detention', 'vulnerability', or 'coercion', stand in its way to circumscribe the scope of its protection. However, the further the person is from the State's immediate control clearly the harder it will be to establish a claim. What really matters is whether, on the particular facts, the Osman elements can be proven. If the duty is triggered, the focus then turns to the Osman qualifications. These developments are welcome and, whilst there is a risk of defensive practice, in reality public authorities have little to fear. A tide of Article 2 claims seems unlikely, with actions limited to extreme cases owing to the high threshold for engaging the duty and the heavy qualifications to the defence of reasonableness. It does mean, however, that public authorities owe a duty to act reasonably in response to a known real and immediate risk of suicide and, perhaps most importantly, 'reasonably' according to what the Court itself considers to be reasonable following a full merits review.

Despite initially looking to bring the common law into line with ECHR developments, there is a slowly emerging consensus in judicial and academic circles that the two can develop separately. According to Clerk and Lindsell, 'There is a developing understanding that remedies under the [Human Rights Act] are appropriate to the purposes of the statute as a whole, and that there is no need to introduce major changes into tort law in order to protect the same Convention rights through different means' (Clerk, 2012, para 14-92). If this remains the case, the consequence 
will be that the 'public Samaritan' can be required by Osman to act reasonably to minimise real and immediate risks to life without upsetting the private law of negligence. The position of private individuals would thus remain ugly, as they are not bound by Article 2. The same is true for public bodies in those common law systems beyond the Council of Europe with no equivalent to Article 2 ECHR. For them, a known and easily preventable suicidal state of mind in and of itself will be insufficient to establish a duty on others to care.

\section{BIBLIOGRAPHY}

Beatson, J., Grosz, S., Hickman, T., Palmer, S., Singh, R. (2008). Human Rights: Judicial Protection in the United Kingdom. London: Sweet and Maxwell.

Beauchamp, T.L. and Childress, J.F. (2001). Principles of Biomedical Ethics. New York: Oxford University Press.

Brazier, M. and Cave, E. (2011). Medicine, Patients and the Law. London: Penguin.

Brazier, M. (2006). Do No Harm - Do Patients Have Responsibilities Too? Cambridge Law Journal , 65, 397.

Callaghan, D. (1996). Can the Moral Commons Survive Autonomy? Hastings Centre Report, 41.

Callaghan, D. (2003). Principalism and Communitarianism. Journal of Medical Ethics , 29, 287.

Callaghan, S. and Ryan, C. (2011). Refusing medical treatment after attempted suicide: Rethinking capacity and coercive treatment in light of the Kerrie Wooltorton case. Journal of Law and Medicine , 18 (4), 811-819. 
Clerk, J.F. and Lindsell, W.H.B. (2012). On Torts. (A. a. Dugdale, Ed.) London: Sweet and Maxwell.

Coggon, J. (2006). Could the right to die with dignity represent a new right to die in English Law? Medical Law Review , 14, 219-237.

Donnelly, M. (2010). Healthcare Decision-Making and the Law: Autonomy, Capacity and the Limits of Liberalism. Cambridge: Cambridge University Press.

Du Bois, F. (2012). Social Purposes, Fundamental Rights and the Judicial Development of Private Law. In Nolan, D. and Robertson A., Rights and Private Law (p. 593). Oxford: Hart Publishing.

Dworkin, R. (1993). Life's Dominion: An Argument About Abortion, Euthanasia, and Individual Freedom. New York: Alfred A. Knopf.

Dyer, C. (2009). Coroner rules that treating 26 year old woman who wanted to die would have been unlawful. British Medical Journal , 339, 4070.

Etzioni, A. (2011). Authoritarianism versus Responsive Communitarian Bioethics. Journal of Medical Ethics , 37 (1), 17-23.

Fulbrook, J. (2013). Rescuers and the concept of a "negligent rescue" . Journal of Personal Injury Law, 81.

Gordley, J. and von Mehren, A.T. (2006). An Introduction to the Comparative Study of Private Law. Cambridge: Cambridge University Press.

Hewitt, J. (2013). Why are people with mental illness excluded from the rational suicide debate? International Journal of Law and Psychiatry .

Kant, I. (1964). Groundwork of the Metaphysics of Morals. New York: Harper and Row. 
Large, M., Ryan, C., Singh, S., Paton, M., Nielssen, O. (2011). The Predictive Value of Risk Categorization in Schizophrenia. Harvard Review of Psychiatry, 19 (1), 25-33.

Large, M., Ryan, C., Nielssen, O. (2011). The validity and utility of risk assessment for inpatient suicide. Australasian Psychiatry, 19 (6), 507-512.

Large, M., Sharma, S., Cannon, E., Ryan, C., Nielssen, O. (2011). Risk factors for suicide within a year of discharge from psychiatric hospital: a systematic meta-analysis. Australian and New Zealand Journal of Psychiatry, 45 (8), 619-628.

Malm, H. (2000). Bad Samaritan Laws: Harm, Help or Hype? Law and Philoshopy, 19, 707.

Malm, H. (1995). Liberalism, Bad Samaritan Law, and Legal Paternalism. Ethics , 106 (1), 4-31.

McBride, J. (1999). Protecting life: a positive obligation to help. European Law Review, 43.

McLean, S. (2009). Live and let die. British Medical Journal , 339, 4112.

Mill, J. (1859). On Liberty. London: John W. Parker and son.

Nolan, D. (2013). Negligence and Human Rights Law: The Case for Separate Development. Modern Law Review , 76 (2), 286-318.

Nolan, D. (2011). The Liability of Public Authorities for Failing to Confer Benefits. Law Quarterly Review , 127, 260.

Ryan, C., Nielssen, O., Paton, M., Large, M. (2010). Clinical decisions in psychiatry should not be based on risk assessment. Australasian Psychiatry , 18 (5), 398-403.

Ryan, C., Nielssen, O., Paton, M.B., Large, M. (2010). Clinical decisions in psychiatry should not be based on risk-assessment. Australasian Psychiatry, 18 (5), 398-403.

Schramme, T. (2013). Rational suicide, assisted suicide, and indirect legal paternalism. International Journal of Law and Psychiatry . 
Singh, J.P., Grann, M., Fazel, S. (2011). A comparative study of violence risk assessment tools: a systematic review and metaregression analysis of 68 studies involving 25,980 participants. Clinical Psychology Review , 31, 499-513.

Spencer, J. (2008). Tort law Bows to the Human Rights Act. Cambridge Law Journal , 67 (1), 15-17.

Szmukler, G. (2003). Risk assessment: 'numbers' and 'values'. Psychiatric Bulletin , 27, 205-207.

Wicks, E. (2010). The Right to Refuse Medical Treatment under the European Convention on Human Rights. Medical Law Review , 9, 17. 